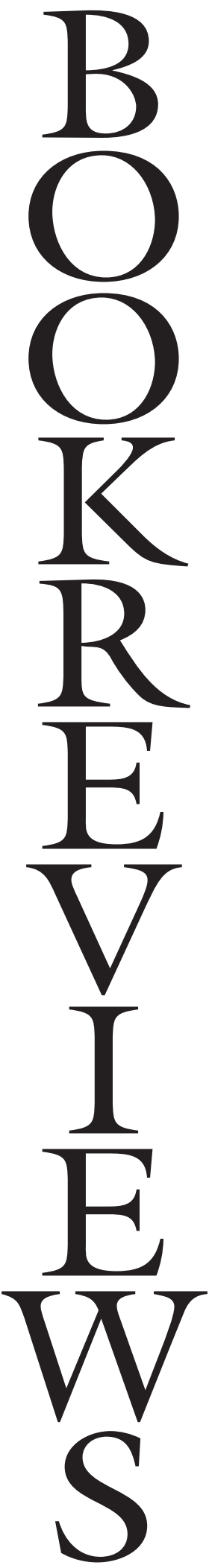

DEATH:

\title{
A MORBIDLY INTERESTING FIRESIDE COMPANION
}

Joanna Ebenstein (ed.): Death: A Graveside Companion. Thames \& Hudson, 2017, 368 pages. Price: $\$ 40$.

$A \mathrm{n}$ academic book review might be the a book by its cover". Nonetheless, this reader was struck by the beauty of editor Joanna Ebenstein's Death: A Graveside Companion (2017) upon first glance. The book has decorative elements that are foil-stamped in coppertones around the binding, chief among them the casually lounging figure of Death themselves on the cascading titular word Death. It is immediately eye-catching, and invites the reader into the well of art inside the volume. Not to be falsely advertised by its outside, the paper within the bindings is done in the same color scheme and with the same attention to detail. The pages of the book are of thicker paper and, interestingly, umber colored with a lighter brown font, which makes the book feel luxurious. The illustrated pages are glossy with a similar thickness, which does justice to a book so heavily reliant on illustrations. All in all, this is a book of striking first impressions, not only for the controversial nature of its theme but also for its artful presentation of it.

\section{DEATH'S ALTERNATIVE (ART) HISTORY}

The Companion is a collection of texts thematically arranged in chapters, rather than revolving around making one central argument about death as such. There are seven chapters in total, ranging from different representations of death in anatomy, theater, early history and literature to popular culture and fine arts. Ebenstein describes the collected impression of the pieces within the book as an "alternative art history" (p. 8), where the central interest is not beauty or sexuality or pain, but rather how all of these themes and 
more are found in contemplations of death. In the anthology, the authors are observing themselves or us (in the meaning of humankind) observing death. The collection marries art and medical history through the way in which death has figured as a somber spectacle in the human imagination. As Ebenstein puts it: "Death: A Graveside Companion can be seen as a treasury of images (...) related to humanity's attempts to imagine and understand death. (...) [and it] does not seek to be encyclopedic" (p. 14). It most definitely achieves this goal. Ebenstein "hope[s] that this book might act as a gesture towards redeeming death (...) [and] the seemingly paradoxical notion that it is precisely by keeping death close at hand and coming to terms with its inevitability that we are able to lead full rich lives." (p. 16). With this mission statement, Ebenstein writes herself into the death positive discourse. Death positivity is a contemporary amorphous movement reacting against the reluctance to acknowledge death in mainstream society. It works to dismantle different taboos around death, not only the instance itself but also the speaking of and interest in the culture around death that to many might seem morbid. The death positive movement is largely based in the USA, and Ebenstein's selection of texts represents this. She acknowledges that most of the texts consider death as it is seen in a Western Christian tradition (p. 12), although Eva Aridjis' "Death in Ancient and Present-Day Mexico" also examines American pre-colonial death rites. The selection of texts aligns with the general idea in death positivity that there is a historically peculiar way that modern Western society deals with death. Here, a broader culturally comparative base could have illuminated the presumed differences between different cultures to bolster this argument.

\section{A COLLECTION OF CURIOSA}

The beauty of the book also poses a functional problem: the readability of the text is quite diminished in undimmed light, but this is perhaps a book best read by a fire hearth, taken from the shelf and admired for its art, rather than a seminal work on death culture.

For someone who is curious about death, maybe particularly in art, Death: A Graveside Companion is an invaluable starting point for branching out into different areas. The collection would do great as reading material in any academic art history course, and similarly the whole of chapter 2, "Examining the Dead", adds valuable insight on the history of anatomy in the medical sciences. About the illustrations of this chapter, Ebenstein states that the intersecting of art and anatomy "serves as a reminder that anatomy in the 18th century was viewed as a fashionable and progressive pursuit appropriate for gentlemen, and that lavishly illustrated anatomy books were luxurious collectibles intended for a non-specialist audience." (p. 68). The Companion seems to have taken a leaf out of this book, so to speak. The book itself, the object, serves as a memento mori alongside its informational contents, not quite unlike the memento mori ex libris' (identifying bookplates) Ebenstein has collected for the illustrations of chapter 5, "Symbolizing Death". Ebenstein traverses a very self-conscious line of knowledge about the subject the collection presents, and works with it as illustrated above in a way that makes the collection cohesive and remarkable. Still, this reader is left with a feeling of wanting more. For someone who is more well-versed in the history of ideas of death, the book can be supplemental for understanding different takes on death and expanding knowledge of its different historical iterations, but it is perhaps more a collection of curiosa than a revolutionary work on death.

Alexandra Lovais Kristinnsdottir
Master's student
Centre for Gender Research
University of Oslo

Alexandra Lovais Kristinnsdottir

University of Oslo 


\section{WHILE THE DEAD LABOUR FOR THE LIVING}

Laqueur, Thomas W.: The Work of the Dead: a Cultural History of Mortal Remains.

Princeton University Press, 2015, 711 pp,

hardcover 262,26 Dkr; paperback 183,49 Dkr.

\section{With The Work of the Dead: a Cultural History of Mortal Remains Thomas W.}

Laqueur offers an overwhelmingly rich anthropological and historical examination of the meaning of death and the dead body in the context of Western Europe and NorthAmerica from the Middle Ages to the present with a focus on the eighteenth century onward. To examine his book's central question, namely, "why the dead body matters" (p. 1), the author invokes Diogenes' cynicist demand that his lifeless body be tossed away and eaten by beasts (ibidem.). The outcome of this radical opening is a tracing of the meaning of the dead body nevertheless - through its cultural significations and existential impacts in time and across spaces it has occupied. Traversing an impressive range of equally captivating and outrageous historical encounters with religious, political and capital stakeholders in the dead body, Laqueur persists in his argument that the dead matter because the 'work' they do "is to make culture and set the boundaries of our mortality" (p. 13).

The book has four parts. In the first Laqueur grounds his main argument in deep time asserting that, in spite of localised variations, the dead have mattered 'always' and 'everywhere' in significantly similar ways (p. 31). To support this universalising claim he enacts an anthropological lens to identify the cultural persistence of care for the dead body, across changing religious schemes of sacra-lisation, philosophical cynicism and secular necromancy, as praxes for attributing mean-ing to the 'nothingness' death is ( $\mathrm{p}$. 27). Laqueur then casts disparate religious and scientific orientations toward spiritual matters as reflections of a universal "commit- ment to the existence of a person after death" (p. 56). A commitment which, he concludes, is deeply rooted in human psychology and emotion-ality and whose ability to make civilisation is reflected across changing imaginaries of the dead.

Moving into the historically framed remainder of the book, part two explores relations between the dead body and civilisation in the context of the authorities and communities that undertake the care for the corruptible body and the management of the necrogeographies that host its earthly remains. Focusing on the architectural and botanic reconfigurations that came to distinguish the modern cemetery from the churchyard, Laqueur traces a major shift in the communal regimes of memorialisation and religion that define these sites. In so doing, he highlights the socio-economic and cultural bars that determine whose bodies are secured entry by burial and whose are excluded and rendered vulnerable by posthumous corporeal punishment and later to a growing commerce in corpses for autopsy. Laqueur further illustrates the enormous power of these Christian communities by unearthing the role the cemetery played in 19th century hygienic discourse as an unlikely site for the unfolding of modern Enlightenment ideas and scientific discoveries about disease and health.

Part three explores the changing significance of naming the dead. Modern age necronominalism, Laqueur asserts, is an amalgam of the historical practice of name recording evolving at the intersection of modern state bureaucracy, civil rights and the new sensibilities arising around death during World War I. By foregrounding the British state's actual incentive to accommodate the increasing civil demands for identification and proper burial of war casualties, Laqueur begins to illuminate the multiple axes of exclusion that condition the social acknowledgement and corporeal safety following the biopolitical apparatus of modern name registries. 
In the book's final part Laqueur hones in on death in modernity through the lens of crematory science and practice. Cremation, he argues, becomes another unlikely vehicle for the championing of modern technologies as it turns out to accommodate the existential anxieties remaining after the Enlightened exhaustion of, what he terms, earlier times of 'enchanted' beliefs in an afterlife (p. 17). Therefore, Laqueur concludes, it is the technological advancement of cremation that wires a new and literally material epoch into the deep history of, what he perceives as, a universally shared human need to cultivate the 'brute' emptiness death introduces into life.

The Work of the Dead provides an intriguing historical and anthropological view into the changing places and meanings the dead have had in the institutional and intimate infrastructures of North-America and Western Europe. What is gained from Laqueur's tracing of the dead body through its vast cultural produce is an illumination of death's astonishing forcefulness. This impressive collection of sites, I believe, makes The Work of the Dead appealing to readers interested in further unmooring the changing powers of death and mourning. One particularly relevant context for the elaboration of such power is the broad field of scholarship on biopolitics, which Laqueur mentions in passing and only with reference to the work of Michel Foucault. Actually enacting such perspectives would generate crucial insights into the active role death plays in the cultivation of life, historically and under the intensified conditions of late and neoliberal capitalism, with potentially altering effects on the author's central argument.

Lastly, because Laqueur's main claim is itself embedded in the Enlightenment worldview he considers a main catalyst of Western 'disenchantment' (p. 210), readers may also be moved to examine the consequences of the essentialising humanism that frames this main proposition. Namely the subordination of the dead to a role as labourers for the cultural reaffirmation of the world as it is should inspire interrogation of the hierarchies that underpin, and are generated by, the evident-ness with which human death is ontologised as 'nothingness' (p. 341). Here, the insights poststructuralist (Cixous 1981; Derrida 1994), postcolonial and black feminisms (Sharpe 2006; Hartman 2008), the new materialisms and posthumanisms (Grosz 2004; Barad 2010) have brought to bear on the foreclosures Western representationalism and taxonomisation have enacted on what matters as life and for living emerge as undeniable resources. The radically embodied and mythically poetic alternatives such scholarship offer to positivist and anthropocentric renditions of the world not only illuminate the reductiveness that has historically and presently informed conventional Western knowledge production, they expand its boundaries (eg. Haraway 2004; Barad 2007). These forcefully growing efforts to rethink life itself will continue to push for significant reconfiguration of the status and matter of death through the radically worldchanging effects it has on the living.

\section{LITERATURE}

- Barad, Karen. 2010. Hauntological Relations of Inheritance: Dis/Continuities, SpaceTime Enfoldings, and Justice-to-Come. Derrida Today. 3(2), 240-68.

- Barad, K. 2007. Meeting the Universe Halfway: Quantum Physics and the Entanglement of Matter and Meaning. Duke University Press.

. Cixous, Hélène. 1981. Castration or

Decapitation?. Signs: Journal of Women in Culture and Society. 7(1), 41-55.

- Derrida, Jacques. 1994. Specters of Marx: The State of the Debt, the Work of Mourning and the New International. Routledge.

- Grosz, Elizabeth. 2004. The Nick of Time:

Politics, Evolution, and the Untimely. Duke

University Press.

- Haraway, Donna. 2004. A Manifesto for Cyborgs. In: The Haraway Reader. New York: Routledge, 7-45. 
- Hartman, Saidiya. 2008. Venus in Two Acts. Small Axe: A Caribbean Journal of Criticism 12(2), 1-14.

. Sharpe, C. 2016. In the Wake: On Blackness and Being. Duke University Press.

\section{Ida Hillerup Hansen}

Ph.D.-candidate in

Comparative Gender Studies

Department of Gender Studies

Central European University

\section{POSTHUMAN ECOLOGIES OF THE CORPSE}

\author{
Erin E. Edwards: The Modernist Corpse: \\ Posthumanism and the Posthumous. \\ University of Minnesota Press, Minneapolis, \\ 2018, 240 pages. Price: $\$ 27$.
}

\section{$\mathrm{E}$ rin E. Edwards' The Modernist Corpse: Posthumanism and the Posthumous offers} a unique study of the critical and creative potential of the corpse in the context of (primarily) American modernist literature and other media. Dead bodies, oftentimes "radically dehumanized" (p. l) and depicted en masse in direct relation to atrocities of colonialism, slavery and World War I, populate modernist literature and art. While many literary theorist whose work focuses on American modernism (as Edwards herself notes), looks at death and corpses through the critical lens of studies on mourning, loss and trauma (e.g. Moglen 2007) and are clearly anchored in the traditional idea of the human subject, Edwards grounds her own "necrocentric perspective" (p. 14) in (feminist) posthumanist theorising. For her, "the corpse in American modernism is involved in a trenchant re-examination of who - and what counts as human and as 'alive' in the early twentieth century" (p. 2). The corpses that come to the fore in American modernist literature are the bodies of those marked as 'not human enough': gendered, racialised, queer, 'othered' in different ways, and rendered 'bare life' (Agamben 2008).

Yet, recuperating these bodies, that is, bringing them to the position of 'full humanity' deserving 'dignity' and appropriate treatment, does not undermine the structures of human exceptionalism, or, as Edwards puts it, "the categorical privileging of the human" (p. 2 ), which is itself premised on the radical dehumanisation and oppression of those expelled from that category. Instead, she employs a form of posthumanism that is "emphatically terrestrial and embodied, interpenetrated with both nature and technology" (p. 5 ) and where the 'posthumous' does not supersede life and the human, but rather, forms part of the continuum of life processes. It builds on Gilles Deleuze and Félix Guattari's understanding of ontology and vitalism, where the human is not exempted from other entities, but, instead, forms part of naturalcultural, human and nonhuman, organic and inorganic sets of assemblages, while being itself an assemblage; or, in other words, a multiplicity of human and nonhuman components and processes. Furthermore, Edwards also borrows Deleuzoguattarian notions of molarity and molecularity, which refer to easily identifiable entities, states and processes (e.g., subjects and structural forms of oppression), on the one hand; and less detectable, molecular forms of being and becoming in both biological (e.g., microbes and their role in the decomposition of dead biomatter) and social sense (e.g., microaggressions forming part of mechanisms of racism, sexism and homophobia), on the other. These two levels are not mutually exclusive; rather, they exist simultaneously and in continuous interaction. In this way, for Edwards, the human corpse is not seen in opposition to other, dead and living, bodies, but instead, is immersed in a complex more-than-human or posthuman "trans-specied" (p. 7) ecology of matters, processes and relations on both macro- and micro-scales. Simultaneously, her analyses pay special attention to a multiplicity of differences and factors composing the bodies that 
come to the fore in The Modernist Corpse: their gender, race, class, queerness and species.

While in the introduction the author clearly and pedagogically explains her entry point, rationale behind the project, theoretical and methodological frameworks, and her contributions to both literary studies and posthumanism research, in chapter one, Inhuman Remains, she invites the reader to engage with William Faulkner's two experimental novels As I Lay Dying (1930) and Absalom! Absalom! (1936). As she argues, both novels deconstruct and undo the conventional "humanist figure and radically excavate the categories of the human and nonhuman upon which American slavery was predicated" (p. 23). This is done, she continues, both by the way dead bodies are depicted and visualised, and by the disassembling of linguistic categories that have traditionally "defined the human against dehumanized others" (p. 24). In Edwards' view, such a change in perception forms the ground for a more materialist and ecological conceptualisation of life.

In chapter two, Autopsy-Optics, Edwards turns to Jean Toomer's novel Cane (1923) and W.E.B. Du Bois's Georgia Negro Exhibit, a collection of photographs and documents first shown at the 1900 Paris Exposition in the context of early-twentieth-century lynching photographs. Throughout the chapter, she looks at the parallels between visual technologies of photography and autopsy, and the ways they become disrupted in the analysed texts, as well as how "anti-optic, auditory, and materialist modes of representation, opposing the visual techniques" (p. 23) allow for a more nuanced and less normative understanding of the body.

Chapter three, Sutures and Grooves, in which Edwards discusses an array of texts (e.g. by Mina Loy), photographs and films (e.g. by Man Ray and James Whale) and a Krazy Kat comic by George Herriman, furthers her examination of human/technology assemblages populating early-twentieth-century cultural productions. She argues that they do not only challenge the ideas of temporality and the opposition between the inhuman' forces of technology and (living and dead) bodies - showing instead moments of interpenetration of the natural and the artificial - but also destabilise the notion of gender.

Questions of gender, sexuality and familial bonds are expanded by Edwards in chapter four, Love and Corpses, in which Djuna Barness' Nightwood (1936) and one of its character's queer sexuality (depicted more through her "figurative and material association" ( $p$. 30 ) with the nonhuman than through the transgression of gender and sexuality norms) opens up the enquiry of "what it would mean to love 'in a posthuman way"'(p. 29). As Edwards argues, in Nightwood life and death are repositioned as "adjacent (...) vital forces resistant to the punctuated beginning and endings of the heteronormative life cycle" ( $p$. 176).

Finally, the book is closed with Coda. In Kind Cuts: Gertrude Stein's Tender Buttons and the Nonhuman Corpse, in which Edwards turns to the omni-presence of the nonhuman corpse "rendered into products that [invisibly] infiltrate many aspects of human life (...) material culture is corpse culture" (p. 192-3). A quote from Upton Sinclair's The Jungle (1906), in which it is enlisted how different items of daily use (e.g. buttons, hairpins, violin strings, fertilisers, etc.), all made with byproducts from the slaughterhouse, require "rivers of hot blood and carloads of moist flesh" (Sinclair 1906, cited p. 192), strengthens her argument for a radically materialist and ecological reconsideration of the corpse in its more-than-human sense. However, in that section of the book, the corpse also becomes linked to the corpus: the body of work. Edwards reflects on the corpus's connections and disconnections to the living bodies of the author and the reader, as well as reading as a form of 'posthuman' activity that cuts into the body of the text and continuously remakes meanings.

In The Modernist Corpse, Edwards elegant- 
ly unpacks modernist literary and visual representations of the corpse, while queering them through a posthumanist lens. By bringing issues of exclusion, oppression and dehumanisation in relation to dead bodies, she touches not only on questions of ontology and ecology, but also of ethico-politics. Yet, the latter could have been explored more. The reader would like to ask: what are or could be the ethico-political consequences of such a rethinking of the corpse? While this seems to remain unanswered, the book brilliantly points to the corpse - material, visceral, immersed in a multiplicity of relations with human and nonhuman others - as a key starting point for asking what life is and might be.

\section{REFERENCES}

- Moglen, S. 2007. Mourning Modernity: Literary Modernism and the Injuries of American Capitalism. Stanford: Stanford University Press.

Marietta Radomska, PhD, Postdoc at Linköping University, SE and University of Helsinki, FI 